\title{
Correction to: Fostering integrated mental models of different professional knowledge domains: instructional approaches and model-based analyses
}

\author{
Thomas Lehmann $^{1}$ (D) Pablo Pirnay-Dummer ${ }^{2} \cdot$ Florian Schmidt-Borcherding $^{1}$
}

Published online: 8 March 2021

(c) Association for Educational Communications and Technology 2021

\section{Correction to: Educational Technology Research and Development (2020) 68:905-927$$
\text { https://doi.org/10.1007/s11423-019-09704-0 }
$$

The article "Fostering integrated mental models of different professional knowledge domains: instructional approaches and model-based analyses", written by Thomas Lehmann, Pablo Pirnay-Dummer, and Florian Schmidt-Borcherding, was originally published electronically on the publisher's internet portal on 13 August 2019 without open access. With the author(s)' decision to opt for Open Choice the copyright of the article changed on 21 January 2021 to (C) The Author(s) 2021 and the article is forthwith distributed under a Creative Commons Attribution 4.0 International License, which permits use, sharing, adaptation, distribution and reproduction in any medium or format, as long as you give appropriate credit to the original author(s) and the source, provide a link to the Creative Commons license, and indicate if changes were made. The images or other third party material in this article are included in the article's Creative Commons license, unless indicated otherwise in a credit line to the material. If material is not included in the article's Creative Commons license and your intended use is not permitted by statutory regulation or exceeds the permitted use, you will need to obtain permission directly from the copyright holder. To view a copy of this license, visit http://creativecommons.org/licenses/by/4.0/.

The original article can be found online at https://doi.org/10.1007/s11423-019-09704-0.

Thomas Lehmann

tlehmann@uni-bremen.de

Pablo Pirnay-Dummer

pablo@pirnay-dummer.de

Florian Schmidt-Borcherding

florian.schmidt-borcherding@uni-bremen.de

1 Research Unit: Learning, Instruction, and Educational Psychology, Faculty of Pedagogical and Educational Sciences, University of Bremen, Universitats-Boulevard 11/13, 28359 Bremen, Germany

2 Department of Educational Psychology, Faculty of Pedagogy, Martin-Luther-University HalleWittenberg, Franckeplatz 1, Haus 5, 06099 Halle, Germany 
Open Access This article is licensed under a Creative Commons Attribution 4.0 International License, which permits use, sharing, adaptation, distribution and reproduction in any medium or format, as long as you give appropriate credit to the original author(s) and the source, provide a link to the Creative Commons licence, and indicate if changes were made. The images or other third party material in this article are included in the article's Creative Commons licence, unless indicated otherwise in a credit line to the material. If material is not included in the article's Creative Commons licence and your intended use is not permitted by statutory regulation or exceeds the permitted use, you will need to obtain permission directly from the copyright holder. To view a copy of this licence, visit http://creativecommons.org/licenses/by/4.0/.

Publisher's Note Springer Nature remains neutral with regard to jurisdictional claims in published maps and institutional affiliations. 